\title{
APAD 1996 : On the move...
}

Thomas Bierschenk

\author{
(2) OpenEdition \\ Journals \\ Édition électronique \\ URL : http://journals.openedition.org/apad/597 \\ DOI : 10.4000/apad.597 \\ ISSN : 1950-6929 \\ Éditeur \\ LIT Verlag
}

Édition imprimée

Date de publication : 1 décembre 1996

Référence électronique

Thomas Bierschenk, «APAD 1996 : On the move... », Bulletin de l'APAD [En ligne], 12 | 1996, mis en ligne le 22 février 2007, consulté le 24 septembre 2020. URL : http://journals.openedition.org/apad/597 ; DOI : https://doi.org/10.4000/apad.597

Ce document a été généré automatiquement le 24 septembre 2020

Bulletin de l'APAD 


\title{
APAD 1996 : On the move...
}

\author{
Thomas Bierschenk
}

1 Like the preceding ( $\left.n^{\circ} 11\right)$ and subsequent $\left(n^{\circ} 13\right)$ issues, this bulletin is very much focused on the Fourth Biannual APAD Congress (les 4èmesJournées APAD) which was held in June 1996 at the University of Hohenheim at Stuttgart in Germany. The theme of the congress was "Negotiated Development. Brokers, Knowledge Systems, Technologies" .

2 In many respects, the Stuttgart congress continued the traditions initiated at the journées APAD in Paris (1991) ${ }^{1}$ and continued in Montpellier (1992) ${ }^{2}$ and Bamako (1994) ${ }^{3}$. It continued the principle of rotation with congresses taking place alternatively in Europe and in Africa since Montpellier. (The next one will be held in Cotonou in 1998 on the theme of "Local Powers, Decentralisation and Social Networks".) Its twin themes ("Local Brokers of Development" and " Negotiated Technologies") were very "APADian" in that they subjected important aspects of the world of "development" to the scrutiny of the anthropologist. It drew the usual "APAD crowd" : anthropologists who believe that social change and development should be privileged domains of scientific inquiry on an equal footing with kinship and religion, representatives of other scientific disciplines and development practitioners (alas not as many as we would have wished) who are interested in anthropological perspectives on development practices. We also kept the successful structure of previous meetings with a high-level key-note speech to start us off (this time given by Benin philosopher Paulin Hountondji) and two days of plenary sessions in the mornings and workshops in the afternoons. Last but not least, apart from its intellectually inspiring atmosphere which impressed not least the new participants, the congress furthered the distinctive associative dynamics which had already been the trademark of our gatherings in Montpellier and Bamako. This, I feel, arises from the ideal mix of people who have known each other for quite some time and who may even have worked together on research projects with new participants attracted by the appeal of the themes to be debated.

On the other hand, the Stuttgart congress was also innovative in several respects. These innovations warrant some explanation, as they may embody signs of things to come - in future bulletins, future congresses and in the future work of APAD in general. First and foremost, this was the first time that APAD was not playing, linguistically speaking, on 
home ground (even though it was, of course, a friendly game and the score was very respectable). English played a much more prominent role at this meeting than at previous ones, although, needless to say, it had never been completely absent from previous congresses (and had even been the medium of a key-note speech by Norman Long in Bamako ${ }^{4}$ ). Pragmatic bilingualism in French and English is one of APAD's working principles in the sense that we aim to attract people who have an active mastery of one and at least a passive knowledge of the other language. In this way, APAD could hopefully make a small contribution to overcoming the cultural dependency of social sciences in Africa, which is reflected in the often exclusive orientation of Frenchspeaking social scientist on French and that of their English-speaking counterparts on US-British discourses, both all too often existing in splendid isolation from research undertaken and literature written in the other language. For very pragmatic reasons, Germany is a good place to overcome APAD's historically very strong concentration on French as the sole effective working language. It is simply impossible to organise a social-science event here that would aspire to attract a large audience and take place exclusively in French. Thus, the rule of the game was that everyone spoke either English or French and we hoped that everyone present would understand each other. This should not pose any problem for social scientists working on Africa : I frankly fail to see how anybody can do any serious work on Africa without at least reading both languages, English and French.

Secondly, this was the first congress which we explicitly opened to non-APAD members and we were delighted when quite a few colleagues from outside the APAD answered our call for papers. Some of their contributions are included in bulletins 11, 12 and 13, which together constitute the conference proceedings. We were initially concerned that these colleagues would get the feeling of having to confront with a bunch of insiders, an in-group (or a "we-group", as anthropologists say) of people who prefer talking within their own familiar circle. However, these fears were not borne out by events and, in my opinion, our discussions ultimately derived great benefit from the contributions of the non-APAD contingent (most of whom, I am pleased to notice, have now joined the association).

5 Thirdly, apart from the more effective adoption of two working languages and the more varied origins of the participants, we also actively tried to present some papers dealing with non-African research sites, and within Africa we tried to break free from our usual hunting grounds of French-speaking West and Central Africa. We must admit, alas, that we were not very successful with this as far as the numbers of papers are concerned. However, we were very pleased with the quality of the papers dealing with East African, South African, Latin American and Asian experiences which provided very useful comparative perspectives for us other Africanists.

While these three innovative aspects should, in my personal opinion, be taken up and developed in future APAD meetings, I have more mixed feelings about another new aspect of our Stuttgart congress: this time we had not one, but two themes for discussion. They were linked by a common concept - development as social negotiation - and, as Pierre- Yves Le Meur points out in his synthesis of our debates, there was a lot of common ground between these two themes. However, this common ground was not, I feel, sufficiently explored: there was only one paper that explicitly addressed the overall theme (that by Jeremy Gould published in this bulletin) and very little crossthematic debate during the congress. 
7 This is not to say that we did not thoroughly enjoy our co-operation with our colleagues from Wageningen, Geert Diemer and Paul Richards, with whom we jointly organised the congress. Contributions to the sub-theme of "Negotiated technologies" for which they were responsible will make up the bulk of the next bulletin $\left(\mathrm{n}^{\circ} 13\right)$ to be published in spring 1997. I would also like to thank the University of Hohenheim and its president, Prof essor Macharzina, for hosting the conference, our sponsors - the Deutsche Forschungsgemeinschaft, the German Society for Technical Co-operation (GTZ), theCentre des Techniques Agricoles (CTA), the Deutsche Stiftung für Entwicklung (DSE), the Land of Baden- Württemberg and Hohenheim's University Association (Unibund) and, finally, Karen Tscheming for her technical competence which was invaluable in the organisation of the event.

8 Finally, a word of explanation on the new format in which the bulletin will appear from this issue onwards. In future, the bulletin will be published by LIT-Verlag (Münster/ Hamburg), the leading Africanist publishing house in Germany, which will possibly also be the publisher of our planned English-language book series. LIT proposed the new size of the bulletin as a way of reducing printing costs and thus also weight and mailing costs. The bulletin will keep its principal structure and remain unchanged in terms of the volume of its contents and will continue to be sent to members who are up to date with their membership fees. Apart from the reduction in costs, the main innovation arising from these changes is that it will now also be available to non-members on sale in book shops.

Towards an anthropology of participatory and decentralised development or why small is not always beautiful

In this bulletin we present some of the contributions on the sub-theme of the Stuttgart congress "Local Brokers of Development", including two papers given in the plenary session (by Kone and Laforge), the other two plenary-session papers on this topic (by Mongbo and Neubert) were already published in bulletin $\mathrm{n}^{\circ} 11$. Many readers will realise that quite a few contributions to this sub-theme are either the direct outcome of, or inspired by, a research programme which was started in 1992 and presented in a previous bulletin ${ }^{5}$, and which, with this number of the APAD bulletin and a forthcoming volume in our French-speaking book series, reaches its culmination ${ }^{6}$.

10 The overall theme of the congress presents "development", including planned development, not as a social engineering task but as an on-going process of negotiation between many actors : local farmers, government extension agents, foreign so-called "experts", researchers... Each of the actors concerned has different objectives, strategies and world views which means that the outcome of these negotiations can never be completely predicted and certainly cannot be planned in advance.

11 Thus, our central concept of "negotiation" reflects the general move - which has marked the last two decades in the thinking about development - away from a "cargo image" of development (a metaphor used in several contributions to our congress), where the main impetus to change is seen as coming from the outside, towards more participatory forms of development interventions that go hand in hand with a general preference for small, private development initiatives. These can be run by private nongovemmental organisations (NGOs), but also - and this is a growing trend not only in Germany - by small and big towns which now often create partnerships with cities or villages in the South. The region around Stuttgart is full of private and local initiatives of this kind: a religious group which helps a village in Togo, groups which market 
mangoes from Africa or coffee from Latin America in so-called alternative networks, others which finance a social worker in the slums of some big city of the Third World, twinning arrangements with a town in India ... Anyone inspired by our conference discussions on the strategies of development brokers who felt like putting theory in action and setting himself or herself up as a development broker would have found any number of potential private donor groups here within a radius of less than $30 \mathrm{~km}$. These development-focused NGOs of the North would constitute a fascinating topic of research to complement our studies on development brokers in the South.

This form of small-scale and decentralised development assistance, which relies on private initiative and privately mobilised resources and circumvents state structures, is believed by many to be closer to the real concerns of "the people" and a more direct answer to their problems.

Reading through the conference contributions, however, the suspicion arises that small is not always so beautiful. Just letting "the population" (or the "grass-roots" or "the poor") decide what they want does not necessarily solve the dilemmas of the development planner. A participatory approach to development planning can easily lead to a situation where the local fishermen in some West African country asked to formulate a strategy to preserve fish reserves in their lagoon can think of no better way to do it than by kicking foreign fishermen out (even if these so-called "foreigners" have been around for three generations), where farmers in a neighbouring country see no need whatsoever for an active policy of preserving natural resources even if there is clear foreboding of a serious ecological crisis, where the ethnic majority in yet another region is quick to appropriate watering points for their own purposes, while the foreign-financed development project which constructed these watering points in the first place had actually intended to help minority Fulani cattle herders water their animals. Or what is to be done when a project tries to "empower the women" while the whole weight of the local social system is against any public political role for women? In other words, the naive belief that a participatory approach is always the best way to find development solutions which are at the same time socially just, inter-culturally acceptable, economically feasible and ecologically viable, turns out to be a populist illusion and no less unrealistic than the technocratic illusions held by some experts from the major development agencies.

As with its twin sister, technocratic illusions of development, the root of the populist illusion lies in the inability to perceive the essentially political character of ail development assistance. Notions like "the population", "the grass-roots", "the poor" , "the women" - key notions of so-called participatory development discourse - conceal two essential facts behind any development intervention :

16 1. They firstly hide the fact that "the poor" (or "the women", or "the grass-roots") are far from a homogenous group with the same problems and objectives. Social reality in all places at ail times al ways consists of economic differences, social hierarchies and unequal distribution of political power between groups and individuals. Therefore, a development project can never directly approach "the population" and will always have to deal with individuals who, rightly or wrongly, claim to speak in the name of "the population" or parts of it. It is these self-appointed spokesmen for their community who, adopting a long-established notion in non-structuralist political anthropology, we call "local brokers of development". 
17 2. Secondly, the ideologically charged discourse of participatory development ignores the fundamental fact that any development assistance is an intervention into a political arena where different strategic groups confront each other. Any development project be it a large project financed by the World Bank, or a small one based on some private initiative - itself becomes an actor in this political field. It will be sought as an ally by those who might try to profit from it for their own purposes and it will be seen by others as a threat to their social position.

Thus, whether the actors involved in it are conscious of it or not, and whether they like it or not, development assistance - be it on a national, macro- or on a local, micro-level is always and first and foremost development policy and even development politics, whereby choices have to be made, sometimes difficult choices, between the interests of different social groups with their conflicting goals, where there are rarely any neat solutions, where progress is only, in the best of cases, incremental and where the bestintentioned initiatives can have unexpected, and often unwanted, consequences.

It is in this area that the anthropology of development, as it is understood within the APAD and outside ${ }^{7}$, has a major role to play. If every development initiative is an intervention into a complex social game then it might well be worth to find out some essential facts before embarking on it: What is at stake? What are the rules of the game? Who are the main players? Which side do we want to be on? Who will profit from our presence? What is the likely price, in sociological terms, of interfering in the on-going game? Who are we going to hurt? Ali of these are essential questions, to which any promoter of a development project, be it big or small, "top-down" or "bottom-up", aiming at "the social engineering of change" or "popular participation in development", needs answers. These are the issues which were addressed, explicitly or implicitly, in the contributions presented at our congress.

\section{NOTES}

1.For the proceedings, see APAD bulletin $\mathrm{n}^{\circ} 1$, Marseilles 1991.

2.Selected contributions to this congress have been published as Jacob, Jean-Pierre \& Philippe Lavigne Delville (eds.), Associations paysannes, Paris : Karthala 1994.

3.For the proceedings, see APAD bulletin $n^{\circ} 8$ (1994).

4.Its French translation was published as "Du paradigme perdu au paradigme ... retrouvé ? Pour une sociologie du développement orientée vers les acteurs, Bulletin de l'APAD 7 (1994) : 11-34.

5.Cf. Olivier de Sardan, J.-P. \& T. Bierschenk, Les courtiers locaux du développement, Bulletin de l'APAD 5 (1993) : 71-76.

6.Some of the relevant work has already been published ; cf. Giorgio Blundo, Les courtiers du développement en milieu rural sénégalais. Anthropologie des intermédiaires locaux dans le système de distribution de l'aide au Saloum Oriental, Cahier des Etudes Africaines 137, XXXV (1995) : 73-99 ; Jerôme Coll, Animateurs et coordinateurs : les courtiers locaux du développement de Malem-Hodar (Sénégal) 
(Working Papers on African Societies. N² 2), Berlin : Das Arabische Buch 1996 ; Eva Sodeik, Interface sans courtiers. Conditions d'émergence du courtage et conséquences de son absence (Working Papers on African Societies $n^{\circ} 4$ ), Berlin : Das Arabische Buch 1996.

7.The work of our colleagues at Wageningen seems to us particularly important in this respect. Cf. note 4 and Long, Norman (ed.), Encounters at the interface, Wageningen 1989. 